\title{
Recognition Between Eudiscoaster and Heliodiscoaster Using Competitive Neural Network
}

\author{
Omar Ahmed AL-Badrani \\ Department of Geology \\ College of Science \\ Mosul University
}

\author{
Raid R. AL-Nima \\ Computer Engineering Dept. \\ Technical college \\ Mosul
}

(Received 14/10/2009, Accepted 14/1/2010)

\begin{abstract}
ABSITRACT
This research is aimed to design an Eudiscoaster and Heliodiscoaster recognition system. There are two main steps to verify the goal. First: applying image processing techniques on the fossils picture for data acquisition. Second: applying neural networks techniques for recognition.

The image processing techniques display the steps for getting a very clear image necessary for extracting data from the acquisition of image. This picture contains the fossils. The picture should be enhanced to bring out the pattern. The enhanced picture is segmented into 144 parts, then an average for every part can easily be computed. These values will be used in the neural network for the recognition.

For neural network techniques, Competitive neural network was used for comparisons. The weights and output values will be stored to be used later in identification. The Competitive network succeeded in identification and attained to $($ False Acceptance Rate $=15 \%$ - False Rejection Rate $=15 \%)$.

\section{التمييز بين الايوديسكواستر و الهيليوديسكواستر باستخدام الثبكة العصبية التنافسية الأكية}

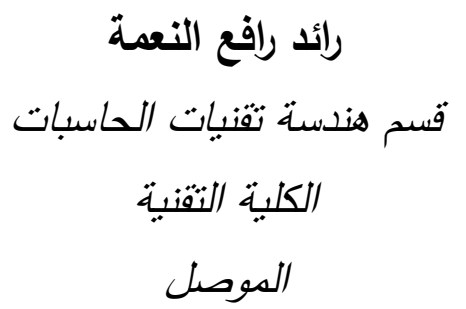

$$
\text { قمر احمد البدراني علية العمد العلوض }
$$
\end{abstract}




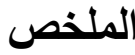

تم في هذا البحث تصميم نظام للتعرف على الايوديسكواستر و الهيليوديسكواستر التابعة لمتحجرات النانو الكلسية بالاعتماد على الثبكة العصبية التتافسية الذكية. حيث تم اعتماد اتجاهين رئيسين للوصول إلى الغاية المنشودة: الأول يتكون من عمليات تحليل صور المتحجرات المجهرية قيد الدرس للتوصل إلى قاعدة بيانات كل نوع، والثاني هو استخدام الثبكة العصبية التتافسية لغرض التمبيز • تتضمن عمليات تحليل الصورة كل العمليات على صورة المتحجر التي تم التقاطها ولغاية الوصول إلى أوضح صورة لاستخراج البيانات منها. تبدأ العملية بالتقاط صورة تحوي على المتحجر ثم سيتم تحسين الصورة، وبعدها سيتم تقسيمها إلى عـ ا جزء، ويمكن بسهولة استخراج معدل كل جزء من هذه الأجزاء. و سيتم استخدام هذه القيم كإخالات لشبكة عصبية من أجل التمبيز . تم استخدام إحدى طرق الثبكات العصبية للمقارنـة وهي الثبكة العصبية التتافسية الذكية. إن قيم الأوزان والإخراج في الثبكة العصبية المستخدمة سيتم خزنها ليتم استعمالها في عملية التمبيز • وقد نجحت

$$
\text { الثبكة وحققت (نسبة خطأ القبول = } 0 \text { \% - نسبة خطأ الرفض = } 0 \text { (1\%). }
$$

\section{INTRODUCTION}

Coccolithophores are planktic unicellular algae belonging to the division (or phylum) Haptophyta which produce coccoliths (calcareous exoskeletal plates). Coccolithophores are in the class Coccolithophyceae (Coccolithophores) first occur in the Late Triassic and are abundant from the Early Jurassic to the Recent.

Discoasteracea includes the calcareous nannofossils of star or rosette shape (Perch-Nielsen, 1985) Flat-lying between remain dark when viewed with crossed nicoles since the $\mathrm{C}$-axis of the calcite then is vertical, most species includeded in Discoaster. Theoorids (1983) suggested Eudiscoaster and Heliodiscoaster and the Discoaster has over 100 species which can be distigushed without majer problems when they are well preserved (Theodoridies, 1983).

There are many researches about the computer recognition or identification process. Like: in 2000 Multimodal Biometric System cleared for face and voice Identification (Frischholz and Dieckmann, 2000), in 2004 physical characteristics systems (such as: fingerprint and retina) are used in picture recognition (Jain, et al., 2004). In 2008 system designed for picture recognition by using linear associative memory neural network (Kasim, 2008).

In geological data, calcareous nannofosils were commonly classified by qualitative description (Perch-Nielsen, 1985), for this reason this study is used for digital classified fort this important grope of fossils which determinate very good age to the beds that contains. 


\section{IMAGE PROCESSING}

\section{1-Image acquisition}

An important and difficult step of this system is image acquisition.

Since fossils is small in size and having color, it is difficult to acquire good images for analysis using the standard Charged Coupled Device (CCD) camera. We have used camera of sufficiently high quality, then preprocessed computerized. In which the process of measurement is being fast, comfortable as well as robust against natural modifications. It employs a digital video camera type (Sony-cyber shot 3X). See (Fig. 1).
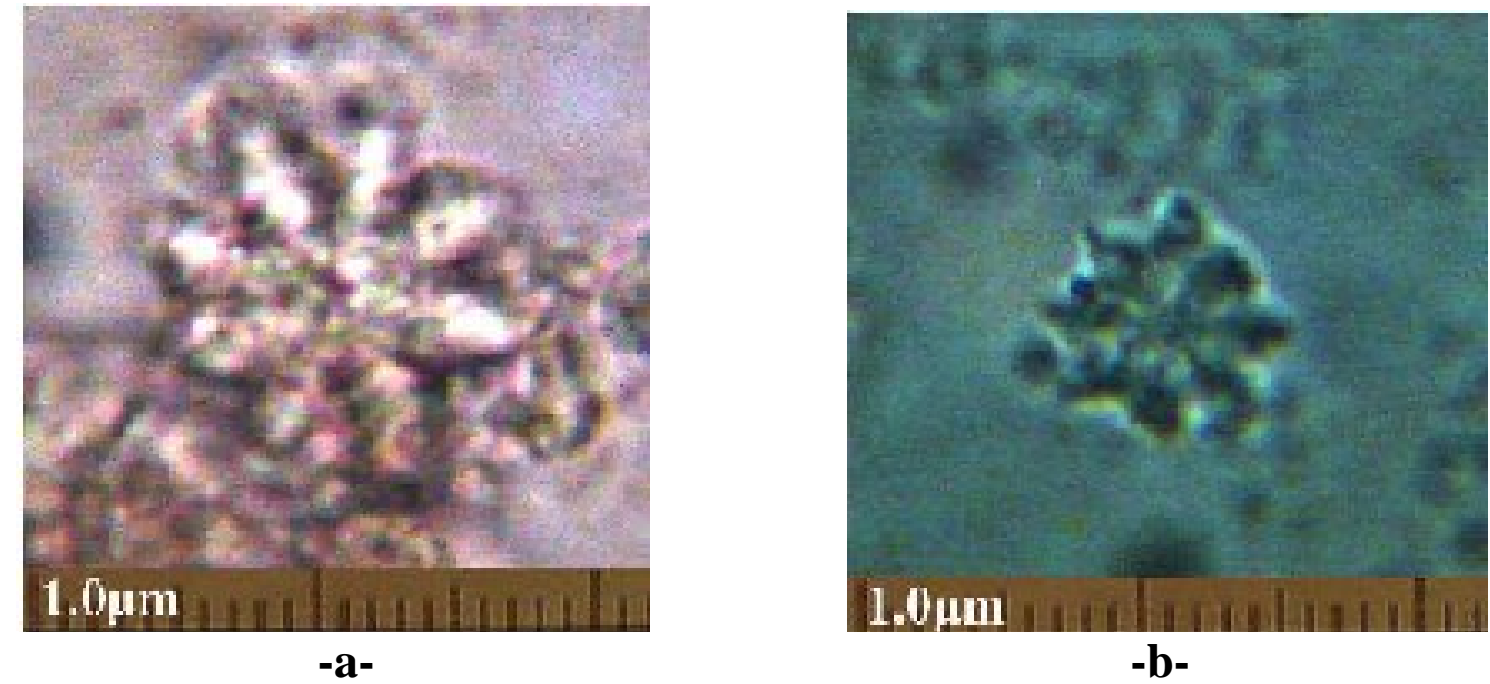

Fig. 1: a- picture of type Eudiscoaster taken by digital camera b- picture of type Heliodiscoaster taken by digital camera

\section{2-Image standardization}

The acquired image always contains not only the 'useful' parts (fossils) but also some 'irrelevant' parts (e.g. sediments). under some conditions, the brightness is not uniformly distributed. In addition, different image-to-camera distance may result in different image sizes of the same image. For the purpose of analysis, the original image needs to be preprocessed.

Therefore, the color image (RGB) should be converts to the gray level image by converts the RGB values to The National Television Systems Committee (NTSC) coordinates, sets the hue and saturation components to zero, and then converts back to RGB color space (The Math Works, 2008). See ( Fig. 2). 


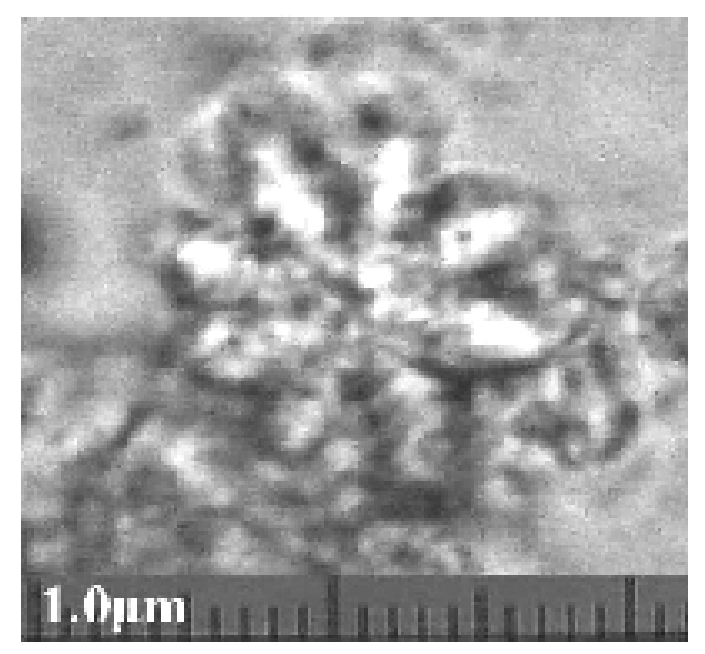

-a-

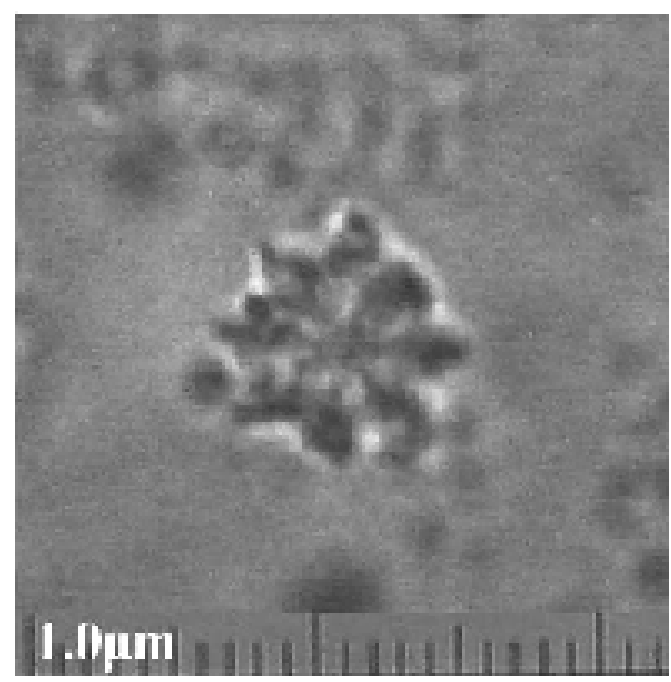

-b-

Fig. 2: a- Gray scale image fortype Eudiscoaster

b- Gray scale image for type Heliodiscoaster

\section{3-Image enhancement}

The original image has low contrast and may have non-uniform illumination caused by the position of the light source. These may impair the result of the texture analysis. Therefore it is necessary enhancing the image to reduce the effect of non-uniform illumination.

So, needing to Perform top-hat filtering to image. By performs morphological top-hat filtering on the grayscale image using the structuring element (SE), where SE must be a single structuring element which it is here creates a flat, disk-shaped structuring element, where by specifying the radius $\mathrm{R}$ which must be a nonnegative integer (The Math Works, 2008). See (Fig. 3) and (Fig. 4).

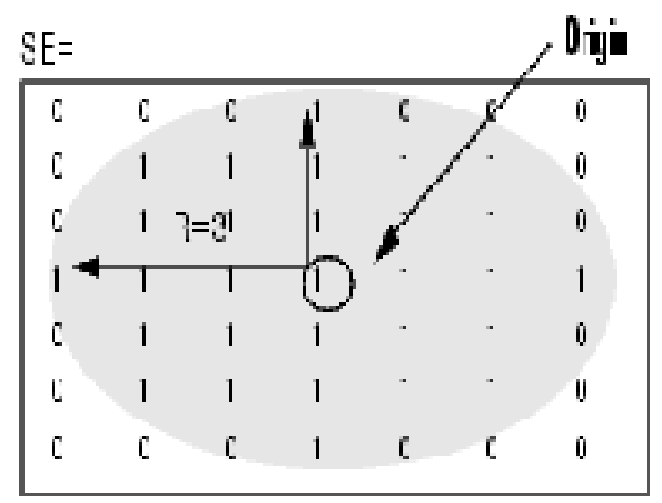

Fig. 3: Structuring element for tophat morphological operation 


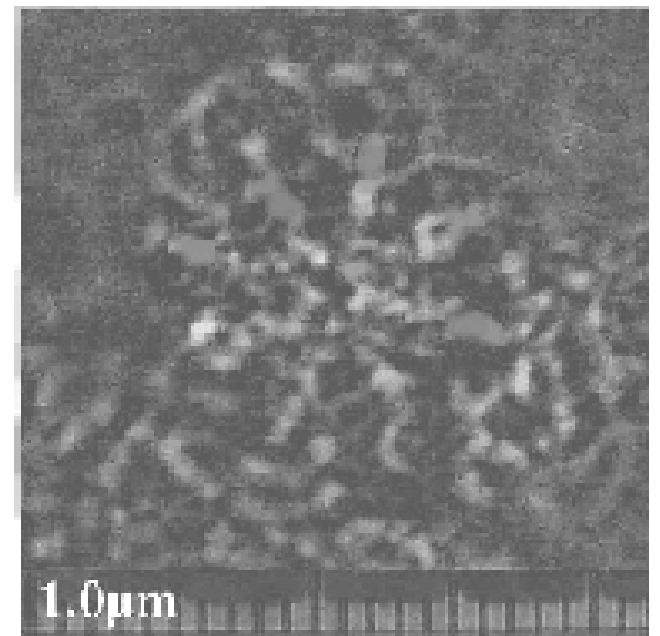

-a-

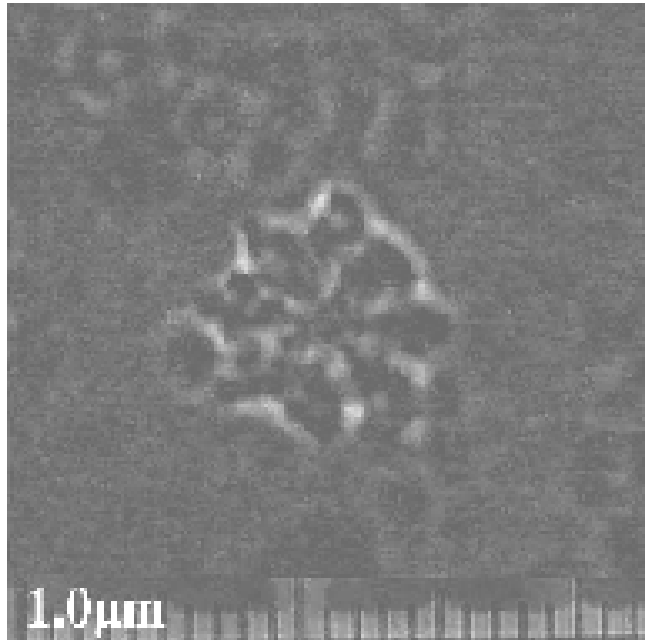

$-b-$

Fig.4: a- Morphological top-hat filtering on the grayscale Eudiscoaster image.

b- Morphological top-hat filtering on the grayscale Heliodiscoaster image.

\section{4-Image cropping}

Since, the resolution of original image equal $577 * 576$ and it has unimportant square boundary. It should be crops to a specified rectangle to reach a resolution equal to $300 * 300$ focused in the image center. See (Fig. 5).

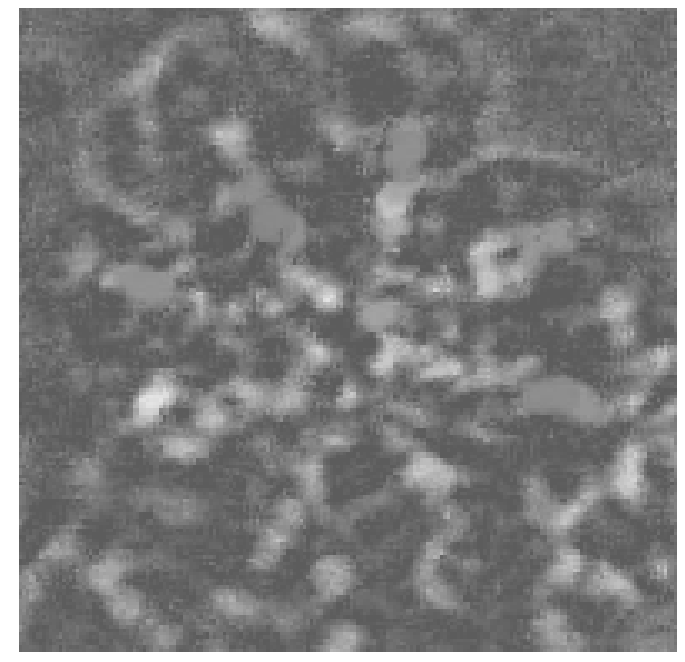

-a-

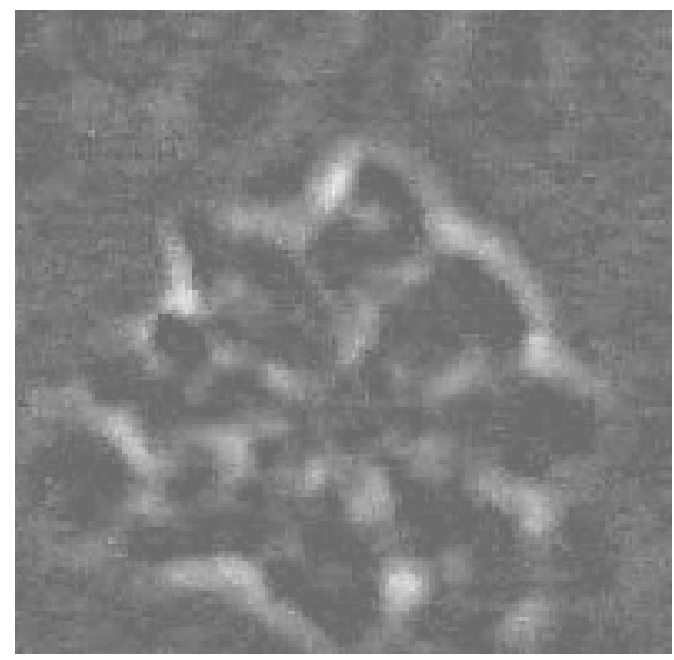

-b-

Fig. 5: a- Image after cropping process for type Eudiscoaster. b- Image after cropping process for type Heliodiscoaster. 


\section{5-Delusion image}

The top-hat filtering to image on gray scale has unneeded boundary details. Therefore, a delusion image (DIM) will be constructed to exhibit the center of image and disappear the boundaries (The Math Works, 2008).

Apart from being circularly symmetric, edges and lines in various directions are treated similarly. The idea taken from the Gaussian blur filters because it have advantage characteristic of they are separable into the product of horizontal and vertical vectors.

So, the delusion image is decomposable in the product of a vertical vector and a horizontal vector (Patina, 2003); the possible vector is shown in equations (1):

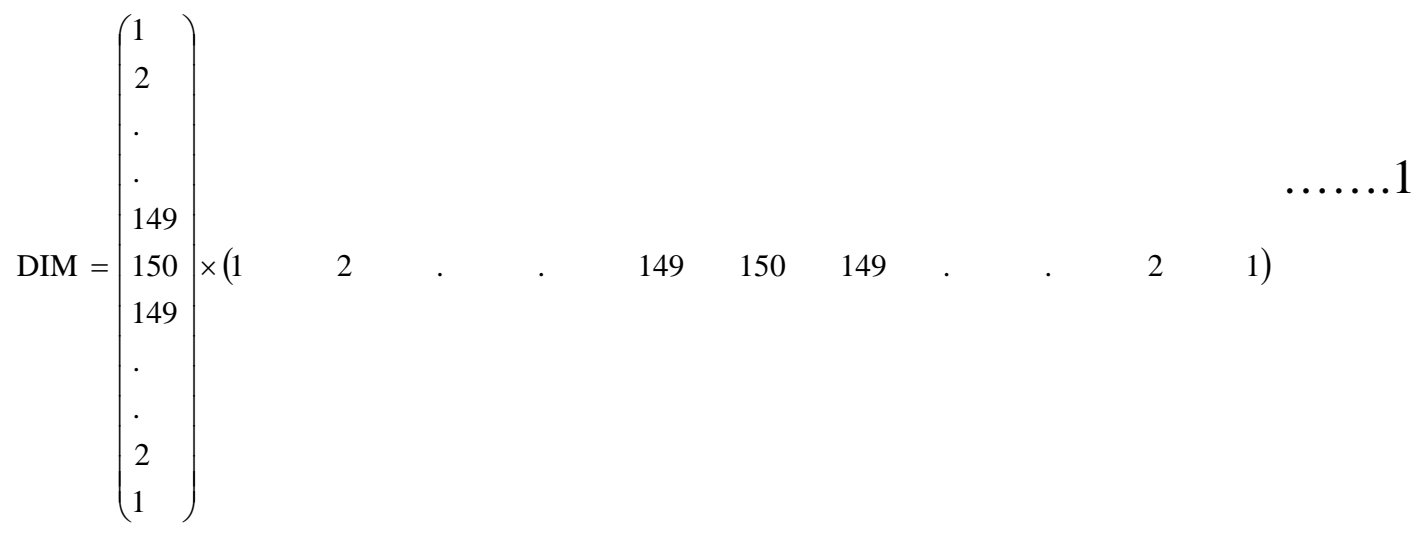

Then to avoid the overload in data, equation (2) can be used: $\mathrm{DIM}_{\text {new }}=0.000001 \times \mathrm{DIM}_{\text {old }}$ 2

Then the DIM will be multiplied by the tophat filtering image to produce the enhanced image as shown in (Fig. 6). This step is important to equalize the values of the previous texture image such that the output image will contain a uniform distribution of intensities. 


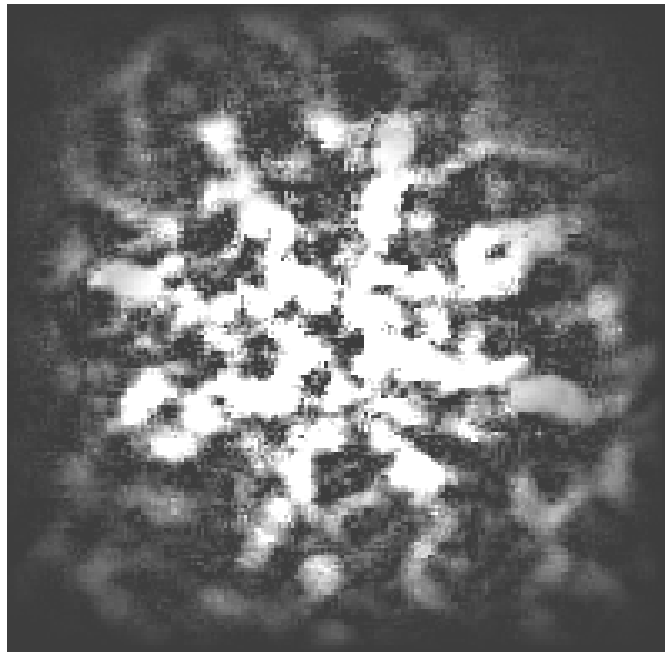

-a-

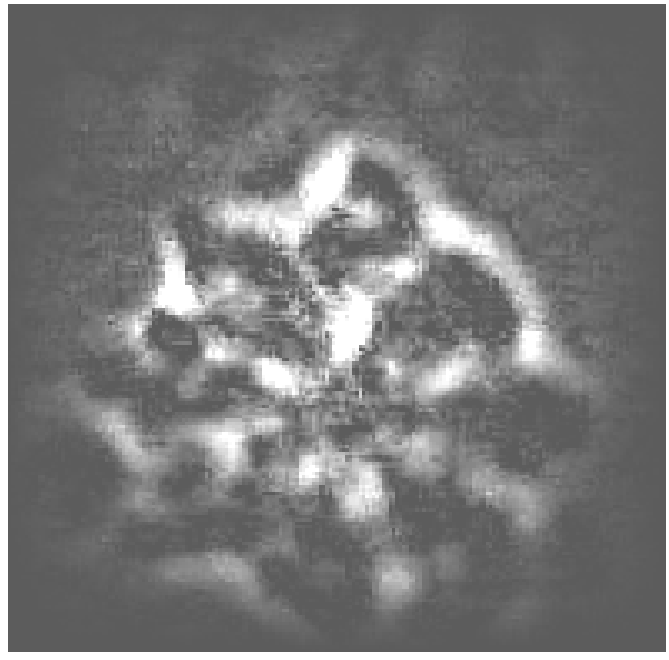

-b-

Fig. 6: a- Enhanced Image for type Eudiscoaster

\section{6- Image segmentation}

b- Enhanced Image for type Heliodiscoaster

The picture can be extracted at this stage in a square box $(12 \times 12)$. As mentioned previously, image segmented into 144 square matrixes (each of $24 \times 24$ pixel) and the average are calculated for each segment as (mean 1 , mean2,........, mean144). These values flow to the neural network input layer. (Fig. $\vee$ ) shows the block diagram of the steps adopted in the image preprocessing.

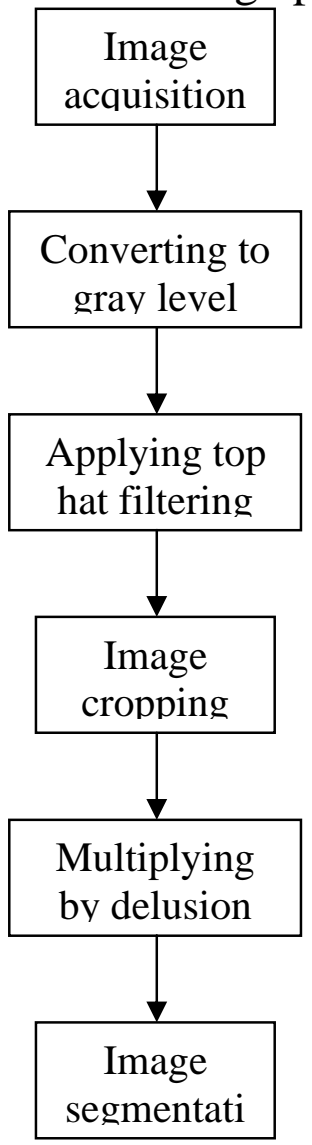


Fig. $\vee$ : The block diagram of the steps adopted in the image preprocessing

\section{NEURAL NETWORKS}

\section{1-Facility of neural networks}

The neural network techniques could be adopted for the purpose of comparison and identification. As is the case with most neural networks, the aim is to train the net to achieve a balance between the ability to respond correctly to the input patterns that are used for training (memorization) and the ability to give reasonable (good) responses to input that is similar, but not identical, to that used in training (generalization) (Mazin R. et. al., 2009).

\section{2- Competitive neural network}

A competitive layer forms a part of a large number of neural networks. It group similar input vectors together without the use of training data to specify what a typical member of each group looks like or to which group each vector belongs. A sequence of input vectors is provided, but no target vectors are apecified. The net modifies the weights so that the most similar input vectors are assigned to the same output (or cluster) unit. The neural net will produce an exemplar (representative) vector for each cluster formed (Fausett, 1994).

\section{3-Architecture of Competitive neural network}

A competitive network learns to categorize the input vectors presented to it. If a neural network only needs to learn to categorize its input vectors, then a competitive network will do. Competitive networks also learn the distribution of inputs by dedicating more neurons to classifying parts of the input space with higher densities of input (Young et al., 1997).

It is a single layer network with unsupervised training, in which the net seeks to find patterns or regularity in the input data.

The architecture for a competitive network is shown in (Fig. ^) below. 


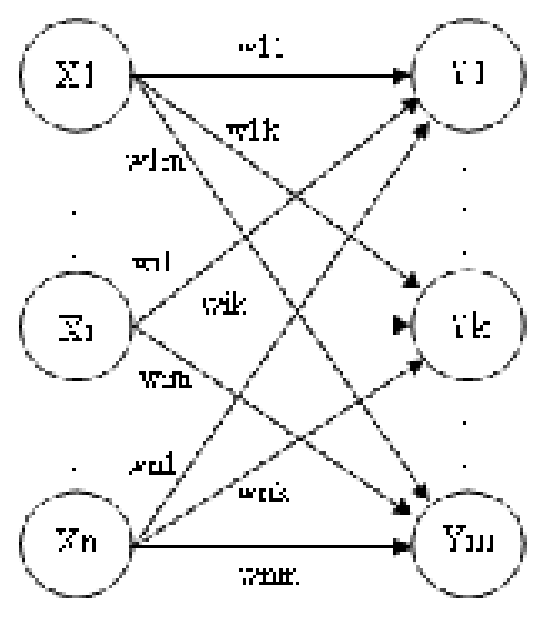

Fig. ^: Architecture of Competitive neural network

The most extreme form of competition among a group of neurons is called Winner Take All. As the name suggests, only one neuron in the competing group will have a nonzero output signal when the competition is completed (Fausett, 1994). It use the dot product of the input vector and the weight vector method for determining the closest weight vector to a pattern vector, where the dot product method is based on the assumption that the weight vector for each cluster (output) unit serves as an exemplar for the input vectors that have been assigned to that unit during training.

\section{4-Suggested Competitive neural network}

The Competitive network which is suggested has 144 nodes in the input layer, two nodes in the output layer. The activation functions used are competitive activation functions in the output layer. By this topology the Competitive network is able to recognize a two clusters between two types of nannofosils.

As mentioned previously, image segmented into 144 square matrixes and the mean array calculated for each segment as (mean1, mean2, ......., mean144). These values flow parallel to the input layer for training.

The Competitive network topology, as shown in Fig. 9, is a single-layer consisting of 144 nodes for input and 2 nodes for output. It has 288 weights and no biases to be stored. The data input stream is parallel for each sample. 


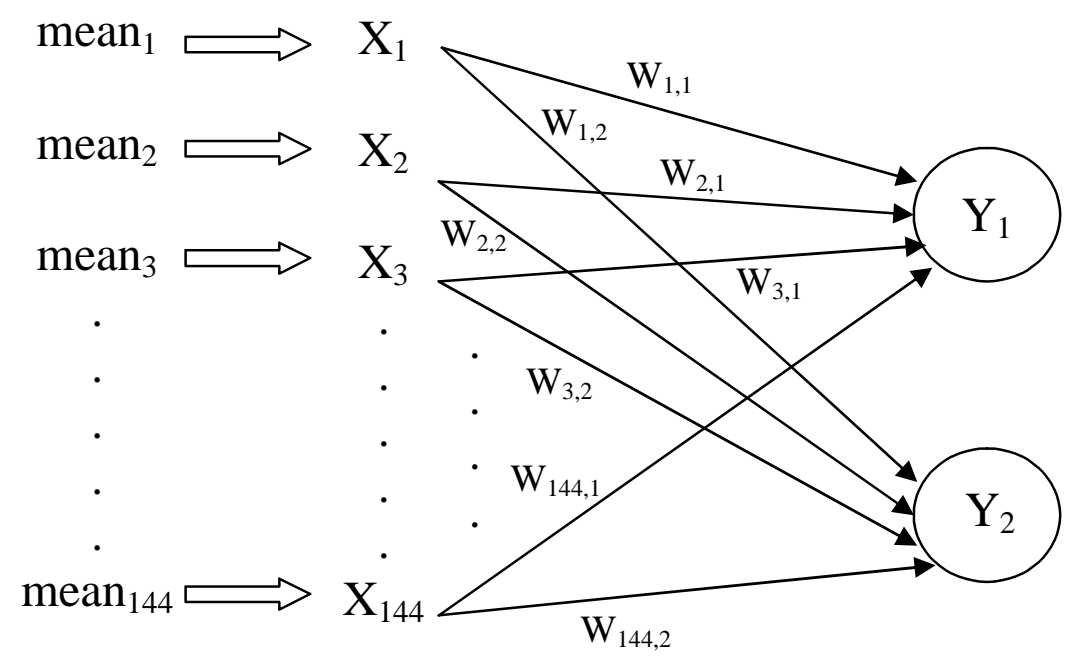

Fig. 9: Suggested competitive neural network

The network trained for 40 samples (20 to each type), and tested for 56 samples. Such that any image introduced to the system could identified if it is on these trained sample or closed enough to its cluster type. The calculated weights are stored in the database and become the comparison base to detect the image. Every image to be tested enters the network in the same way, the output values will be appear to its cluster.

Eudiscoaster, typically Neogene and usually star shape Discoaster with planar contacts surface between elements and Heliodiscoater, typically Paleogene usually rosette shape Discoaster with curved contact surface between elements (Young et al., 1997). Competitive network topology attained FAR 15\% and FRR $15 \%$. Which means that the system had success reached to $85 \%$. The FAR and FRR can be calculated according to the following equations:

FAR $=\frac{\text { Number of accepted imposter claims }}{\text { Total number of imposter accesses }} \times 100 \%$

FRR $=\frac{\text { Number of rejected genuine claims }}{\text { Total number of genuine accesses }} \times 100 \%$

\section{RESULTS}

For pattern image comparisons, Fig. 10 and Fig. 11 clarifies samples for patterns which prove the differences between data patterns before and after image multiplication. These curves illustrates the image segments and their data values levels. In Fig. 11, It converts the image segments to normally Gaussian distributed which appear the middle position for the data after multiplication has highest 
values because of the object position. The other variation of data levels is for the pattern variation according to each segment number.

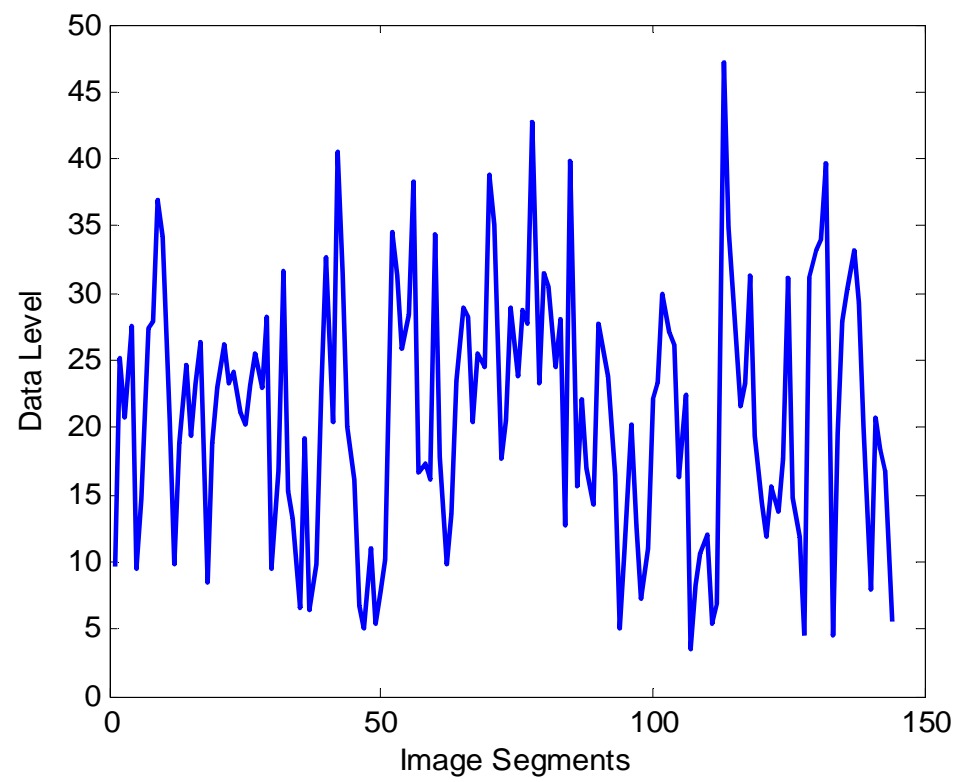

Fig. 10: Data segment levels for sample of image before multiplication

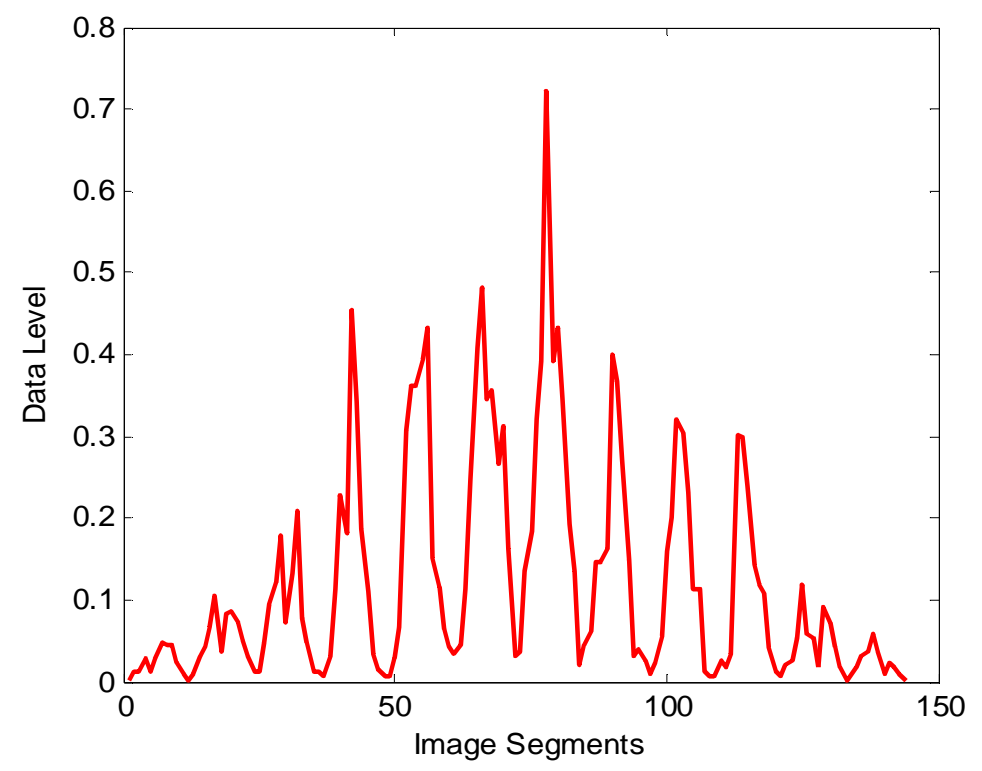

Fig. 11: Data segment levels for sample of image after multiplication

Moreover, it is important to see differences between the images for different types and a convergence between the images for the same type in data values. After image segmentation, taking average values for each image segment may give suitable results because of its features, where it reduces the huge numbers of image data and exhibits the variations between image segments. This step prepares the pattern data to be used in the next stage neural network. Fig. 12 shows that the average values for two images had the same pattern. It proves that image data is nearly for the same type. 


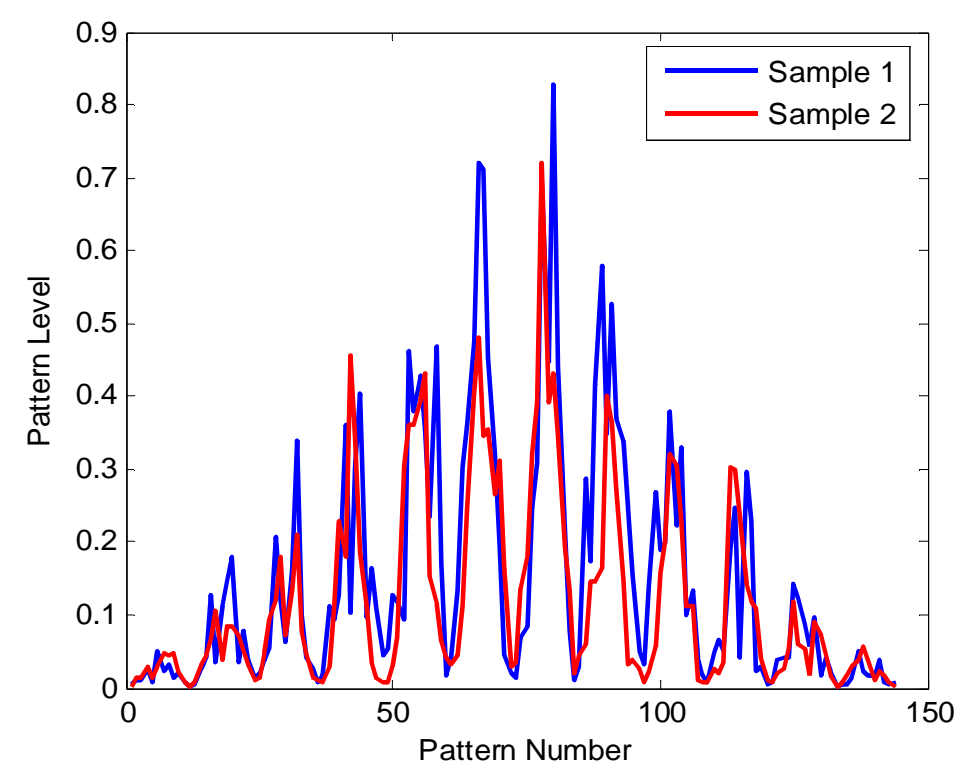

Fig. 12: Mean curves of two segmentation images for the same type

In the previous figure, the average values (patterns) for the same type lead to same curves which close enough together. This equalization for the same images will lead to give different average curves between different iris images. Fig. 13 below shows the differences between samples in different types:

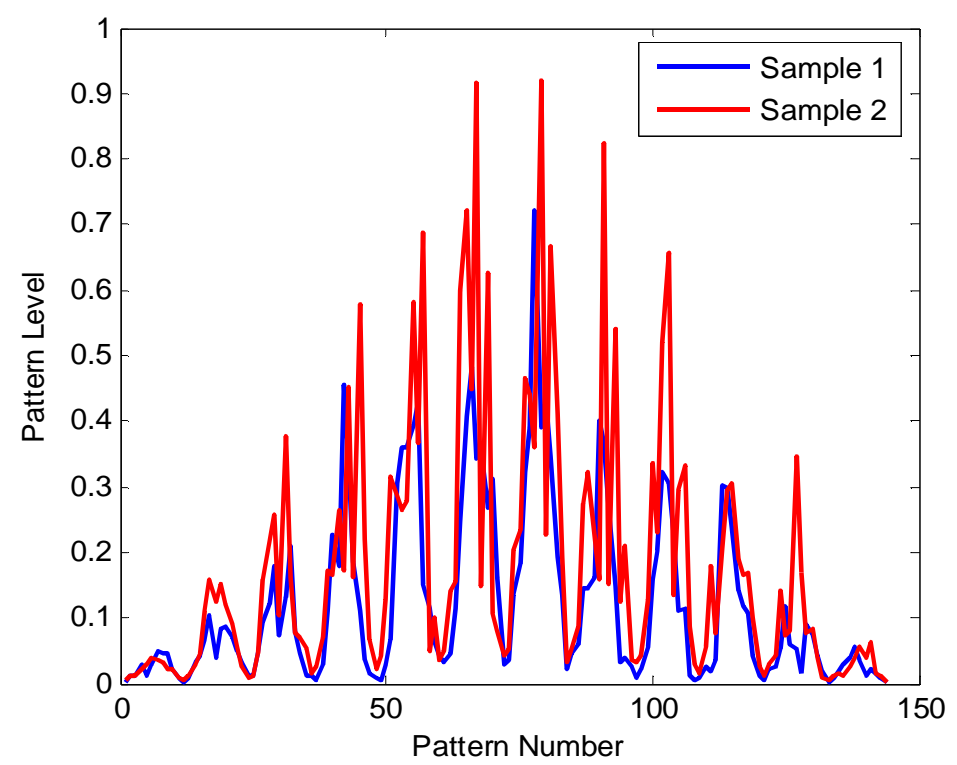

Fig. 13: Mean curves of the different segmentation images

In the previous figures, the Eudiscoaster which represents a star shape has more frequency than the Heliodiscoater which represents rosette shape. That was the reason of clustering and then lead to comparisons. 
Table 1 shows the competitive neural network clustering results after 300 epochs of training.

Table 1: Competitive neural network training results.

\begin{tabular}{|c|c|c|c|c|c|c|c|}
\hline 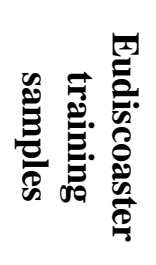 & 童: & 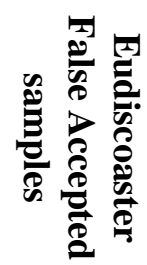 & 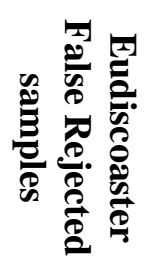 & 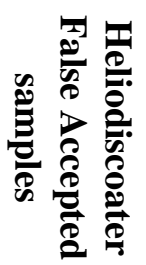 & 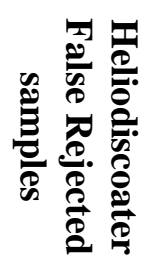 & 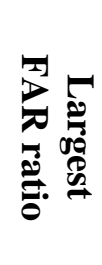 & 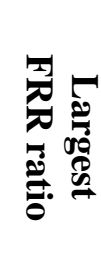 \\
\hline 20 & 20 & 2 & 3 & 3 & 2 & $15 \%$ & $15 \%$ \\
\hline
\end{tabular}

Moreover, the network tested for 56 samples (28 to each type) and reached to FAR and FRR closed enough to the same training results, where just 4 samples (to each type) failed in testing. See table 2 below:

Table 2: Competitive neural network testing results.

\begin{tabular}{|c|c|c|c|c|c|c|c|}
\hline 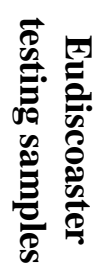 & 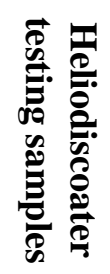 & 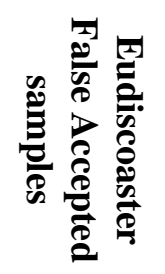 & 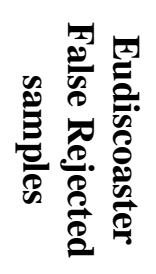 & 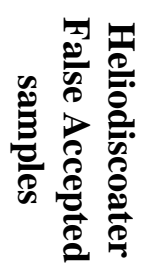 & 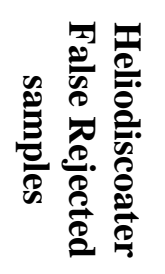 & 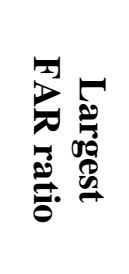 & 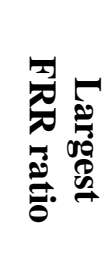 \\
\hline 28 & 28 & 4 & 4 & 4 & 4 & $14.5 \%$ & $14.5 \%$ \\
\hline
\end{tabular}

\section{CONCLUSION}

For neural network techniques, Competitive neural network was used for comparisons. The weights and output values will be stored to be used later in identification. The Competitive network succeeded in identification and attained to (False Acceptance Rate $=15 \%$ - False Rejection Rate $=15 \%)$. Therefore, when input the photo of the calcareous nannofossils the program classified it to either Eudiscoaster then the bed that studied is aged Neogene, or Heliodiscoater then the bed that studied is aged Paleoogene

\section{REFERENCES}


Fausett, L., 1994. Fundamental of Neural Networks, Architectures, Algorithms and applications. Printice Hall Int. Snc.

Frischholz, R. W. and Dieckmann, U., 2000. A Multimodal Biometric Identification System. IEEE Computer, Vol. 33, No. 2, pp. 64 - 68.

Jain, A. K., Ross, A., and Prabhakar, S., 2004. An Introduction to Biometric Recognition. IEEE Transactions on Circuits and Systems for Video Technology, Special Issue on Image- and Video-Based Biometrics, Vol. 14, No. 1.

Kasim,R. R., S., 2008. Picture Recognition by Using Linear Associative Memory Neural Network. Tikrit Journal of Pure Science, Vol. 13, No. 3.

Mazin R., 2009. Personal Identification With Iris Patterns", Al-Rafiden Journal, College of Computer Sciences and Mathematics, Mosul University, Vol. 6, No. 1.pp. 1 - 11

Patina, F., 2003.An Introduction to Digital Image Processing. Homepage yov408, pp. 1 - 49.

Perch-Nielsen, K.,1985. Cenozoic Calcareous Nannofossils. In Bolli, H. M., Saundes, J. B., and Perch-Nielsen, K. (eds.). Plankton stratigraphy. Cambridge University Press, Cambridge, pp.427 - 554.

The Math Works, Inc., 2008.Image Processing Toolbox Use with MATLAB. Version 7.6 MA, USA.

Theodoridies, S.A., 1983. on the legitimacy of the Generic Name Discoaster Tan, 1927ex Tan, 1931. INA Newsletter, 591, 15-21.

Young, J.R., Bergen, J.A., Bown, P.R., Burnett, J.A., Fioentino, A., Jordan, R.W., Kleijne, A., Van Niel, B.E., Ton Romein, A.J., Salis, K.V., 1997.Guide Lines for Coccoliths and Calcareous Nannofossils Terminology. Paleontology, Vol. 40 No. 4, pp. 875 - 912. 